\title{
A REVIEW OF TRIZ TOOLS FOR FORECASTING THE EVOLUTION OF TECHNICAL SYSTEMS
}

\author{
Dorota CHYBOWSKA, Leszek CHYBOWSKI \\ Maritime University of Szczecin
}

\begin{abstract}
:
This article presents tools used in the Theory of Inventive Problem Solving (TRIZ) which are useful when assessing the evolution direction of technical systems. The following matters are discussed: the S-shaped curve, laws (trends and lines) of the evolution of technical systems, multi-screen diagrams, as well as analysis of evolutionary potential. Inventive laws formulated by Gienrich Altshuller as well as laws previously formulated by a Polish writer and promoter of knowledge, Aleksander Głowacki, writing under the pen name Bolesław Prus, have been presented. Finally the innovation roadmaps have been shown. The use of individual tools has been supported by practical examples taken from research performed by the authors, and the usefulness of individual methods was evaluated. All methods have been compared and evaluated.
\end{abstract}

Key words: PRST - laws of the evolution of technical systems, technology forecasting, S-shaped curve, analysis of evolutionary potential, innovation roadmap, TRIZ

\section{INTRODUCTION}

TRIZ is the acronym from the Russian Теория Решения Изобретательских Задач, i.e. "Theory of Inventive Problem Solving" and constitutes an extensive methodology for solving complex technical, marketing, and organizational problems. The creator of this methodology is the Russian inventor and engineer, Gienrich Altshuller (1926-1998). When he worked in the Inventions Section of the Caspian Navy, and analysed many patents, which led him to the conclusion that, since technical systems evolve according to certain rules, these rules can be discovered and used to create algorithms for solving inventive tasks [12].

Even though TRIZ has existed for several decades, it is still not a popular methodology, primarily because of its complexity, the large number methods that are part of the methodology, and the lack of a single standard for them [9]. Nevertheless, if we familiarize ourselves with these methods and use them, we will gain opportunities to develop current technologies and to analyse the potential directions of their evolution, which is one of the key issues in innovation management processes [16, 21, 23]. This observation prompted the authors to compile this work, which discusses and comparatively evaluates which TRIZ methods are the most important and helpful in the analysis of trends during the evolution of complex technical systems.

\section{THE LOGISTIC CURVE}

One of the basic tools for evaluating the evolution of systems is the logistic curve, which is also called the S-shaped curve [32]. This tool, shown in Figure 1, is a good representation of the evolutionary progress of a technical system. Six primary evolution stages can be distinguished on this curve [34]. In stage 1, even before the formation of the technical system, the conditions necessary for the creation of a given system are in place. In stage 2 , due to intensified creative activity, the baseline form of the technical system emerges and slowly evolves. In stage 3, an intensive evolution of the system is observed because of its interaction with users and their positive feedback on the system. The system becomes fully mature in stage 4, wherein inventors begin to run out of concepts and resources to further develop the system and turn their attention towards improving the main parameters of value. In stage 5 , due to the evolution of competitive systems which have superior characteristics, the system's aging process begins. Stage 6 corresponds to the regression of the system because of its limited, but still present, applicability.

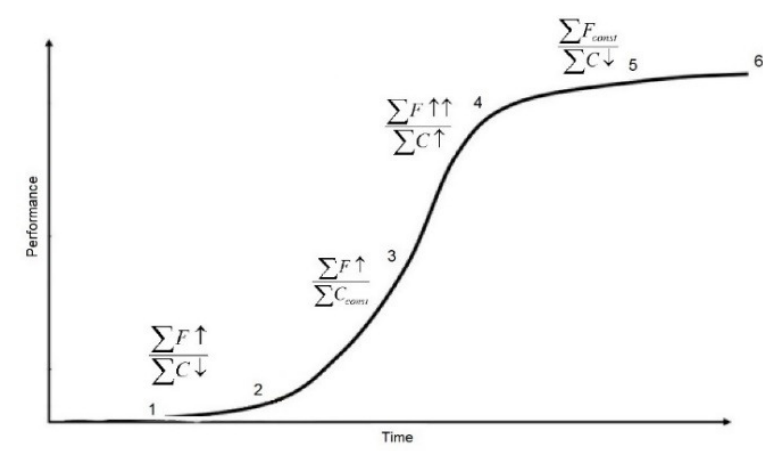

Fig. 1 The curve of the total evolutionary progress of the technical system. Dynamics of changes described by functionality $F$ and costs $C$.

Source: [21, 31] 
The S-shaped curve of system evolution is substantially related to the inventive number and level, as well as the profitability of the system implementation [24, 31]. These relationships are shown in Figure 2.

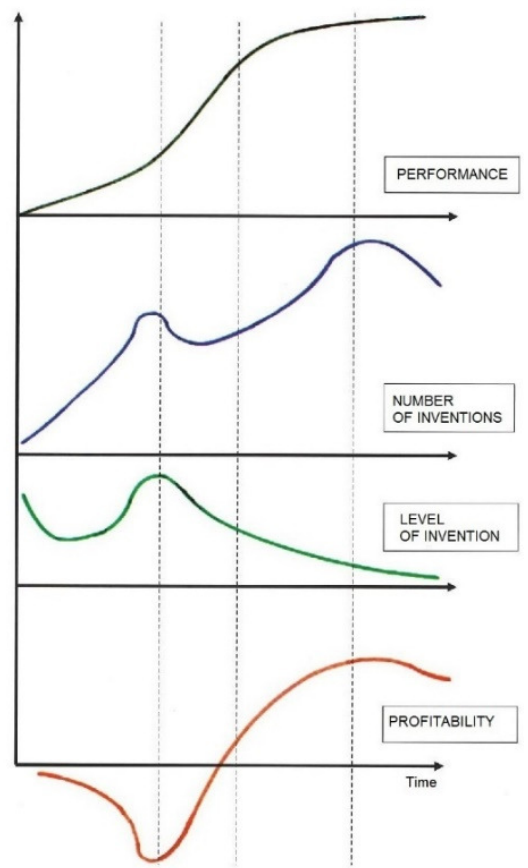

Fig. 2 Relationships between the function of the S-shaped curve, inventiveness, and profitability over the course of evolution of a technical system

Source: $[31,29]$.

Once the evolving system has reached the endpoint of the $S$ curve, further use of the product is possible by identifying market niches in which the current system can be applied. On the other hand, the further development of the product in the initial area of application is possible by making significant changes to the system, such as new functionalities that suit customer expectations. Therefore, this region of the curve is the implementation of another system and the transition to a new S-shaped curve of system evolution. The next curve illustrates the development of the system resulting from the improvement of the reset main parameter of value.

Figure 3 presents the system evolution and transition to successive curves that describes new parameters of value that are relevant for users, using the development of telephony as an example.

The example shown in Figure 3 illustrates how the needs of telephone network users change over time, which corresponds to the transition of the system to successive $S$ curves after reaching the maturity level by attaining a specified main parameter of value. The key aspect in the initial development of telephony was the development of infrastructure, building a distributed telephone network, and the provision of an effective connection system. The next stage was the introduction and refining of the mobility of telephone systems. The introduction of mobile phones led manufacturers to meet the requirements for improving the quality of calls and to maximize the channel capacity. Further development led to the creation of smartphones, devices that integrated various functions previously available in autonomous systems (voice calls, text messages, multimedia messages, email, radio, multimedia player, calculator, organizer, calendar, mobile applications, etc.).

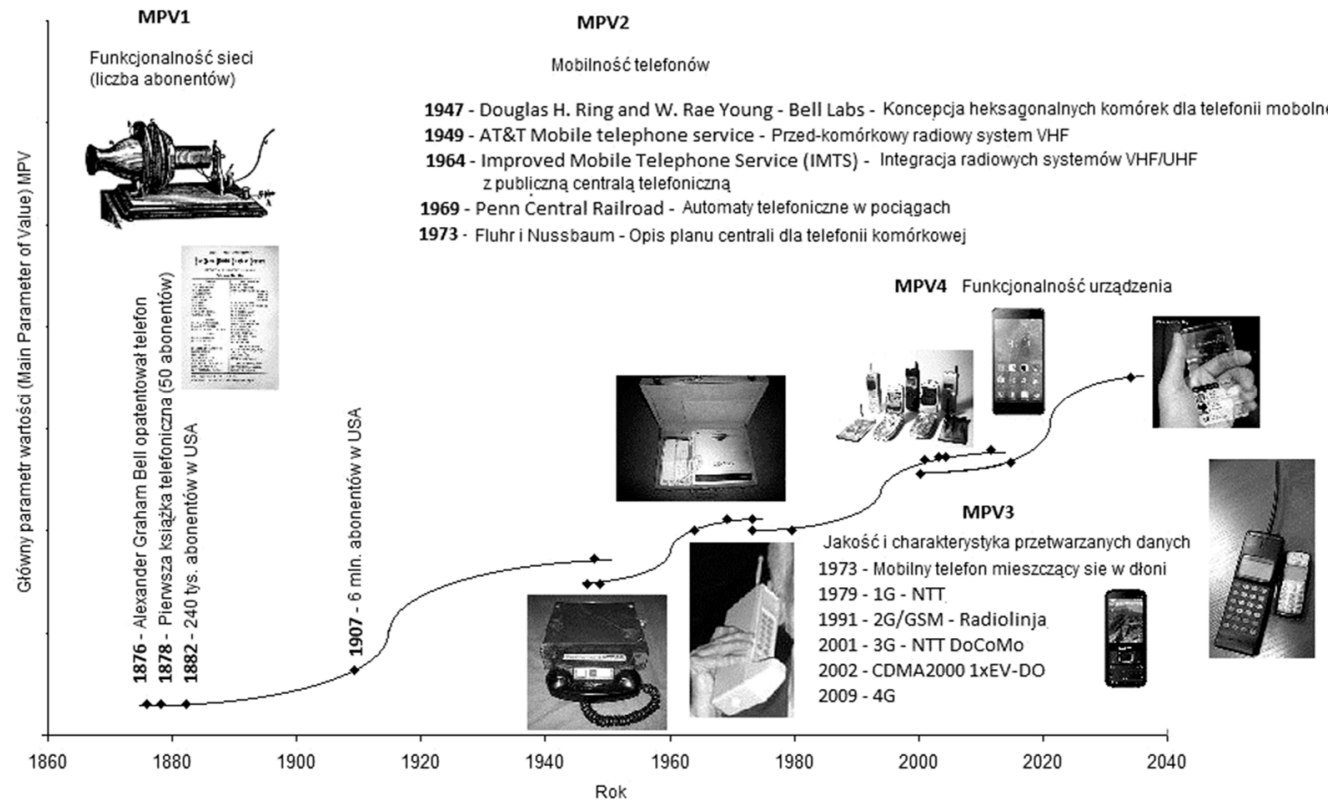

Fig. 3 A combined telephony development model based on three S-shaped curves Source: (author's compilation). 


\section{TRIZ LAWS AND TRENDS OF TECHNOLOGY EVOLUTION}

As early as 1873, a Polish writer and promoter of knowledge, Aleksander Głowacki, writing under the pen name Bolesław Prus, proclaimed three main laws of inventiveness [29]:

- The law of graduality: no invention or discovery is immediately perfect, but rather it is created through gradual improvement;

- The law of dependence: each invention or discovery can only be made based on knowledge of previous inventions and discoveries;

- The law of combination: each invention or discovery is a combination of earlier discoveries and inventions.

More than 80 years later, Gienrich Altshuller who was developing his life's work - the algorithm of invention also described certain regularities in the evolution of technical systems, which he called "the laws of technical systems evolution" (PRST) [5, 24]. In his work [1], which according to [33] is considered to be the most important of Altshuller's publications, the creator of TRIZ stated that the laws of technical systems' evolution are real, constant, and repetitive relations exist between elements inside the system and those in the external environment. These relationships are involved in the progressive evolution, namely the system transition from one state to another with the purpose to improve its functionality. Altshuller also stated that these laws can be learned and used to develop new ideas. Table 1 summarizes PRST laws proposed in 1975 by Altshuller, who, while maintaining the analogy with the division of mechanics into 3 main branches, classified PRST as follows:

- The laws of statics that apply to new systems;

- The laws of kinematics that apply to the evolution that is independent of conditions in which a system evolves;

- The laws of dynamics that apply to the evolution of systems under specific conditions.

The application of selected laws of evolution are plotted together with an S-shaped curve, and the representation of an increase in the level of a system's Su-Field (substance-field models) using the example of a hammer is presented in Figure 4.

The listed "laws" are neither precise nor absolute, which is why they do not follow the contemporary scientific definition of laws, where they define a constant relationship between properties of things or events. Individual laws of evolution (PRST) include trends (lines) of the evolution of technical systems.

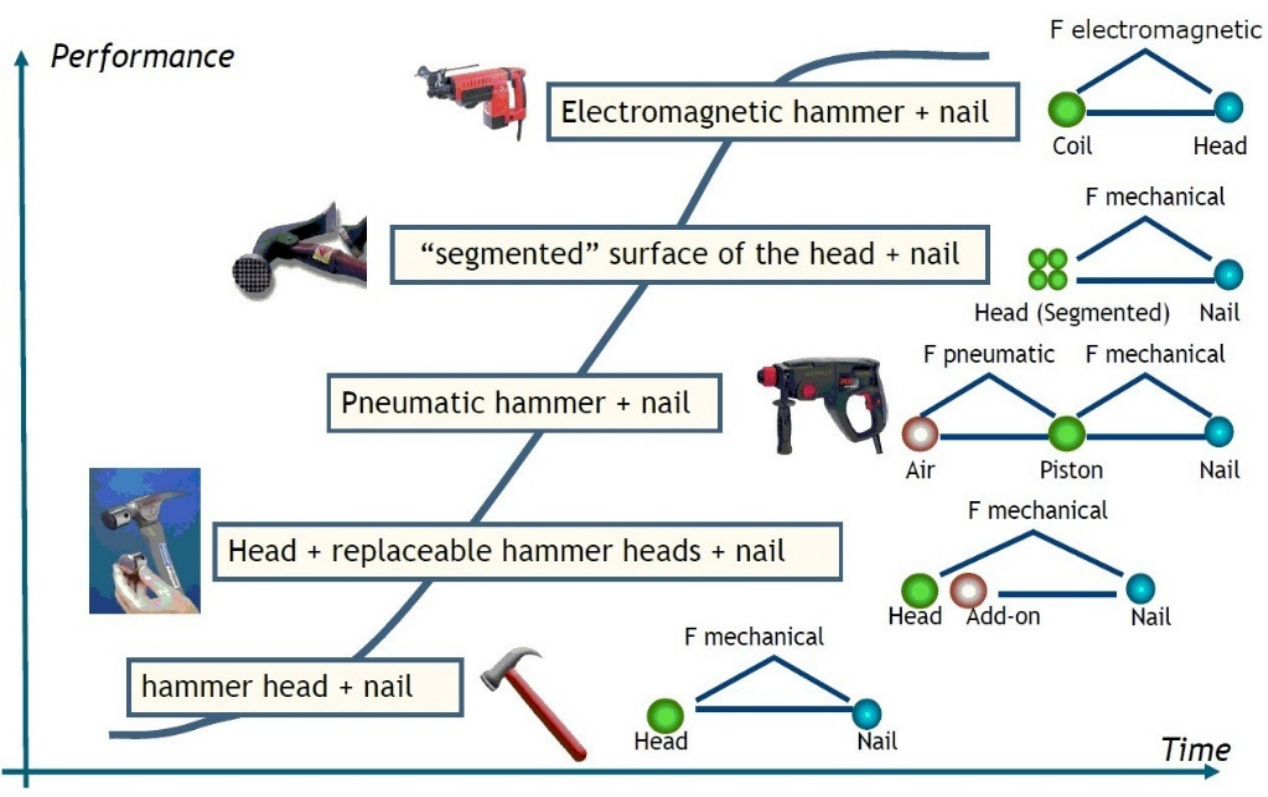

Fig. 4 The increase in the degree of Su-Field interactivity interactions and its relation to evolution of the technical system using the example of a hammer

Source: [34]. 
Table 1

"Laws of the evolution of technical systems" observed by Altshuller

Laws of statics

Law of System Completeness

Each technical system must be composed of 4 fundamental elements: engine, transmission, control unit and working unit. Lines of the evolution of systems:

- Objects with a higher degree of control.

- Fields with a higher degree of control.

- Visible transparency increase.

The evolution of a hammer, from a hewn-stone hammer to a steam hammer made by James Nasmyth in 1842 [4].

- Use of senses.

- Level of Automation Increase.

- Human Involvement Decrease

Law of Energy Conductivity of a System:

The energy conductivity of all parts of the system is the necessary and essential condition for the operation of a technical system. Lines of the evolution of systems:

- Adaptation of a field to existing substance.

Evolution of a mobile phone in terms of increasing transmission speed/data throughput: $1 \mathrm{G}$ (analogue) telephones and $2 \mathrm{G}, 3 \mathrm{G}$ and $4 \mathrm{G}$ respectively.

- Reducing energy loss.

Law of Harmonizing Rhythms of Parts of a System:

The synchronization (or intentional desynchronization) of vibrations (periodic ac- The law uses the intensification of action by changing the tions) of all parts of a system is a necessary and essential condition for the ope- nature of action: continuous to pulse-wise, pulse-wise to ration of a technical system. Lines of the evolution of systems:

- Coordination /de-coordination of operating frequencies.

- Actions coordination.

- Action evolution.

- Shape/form coordination. resonant, resonant to multiplied, and finally to the use of the current wave. An example of implementation of this law is the hand-held drill, which has been improved with the impact feature that makes drilling in walls easier.

Law of Ideality Growth: Laws of kinematics

In line with the assumptions of TRIZ, an ideal system is one of ideality. Lines of the evolution of systems:

system tends to improve effectiveness, reduce the space - Geometry evolution (linear evolution, volumetruic evolution, symmetry, occupied, minimize the weight and operation process duasymmetry).

Law of Uneven Evolution of System Parts:

ration, improve the reliability, etc.

During the last decade, concepts were much more diver-

The evolution of parts of a technical system is non-uniform, meaning that the sified in the development of ship propulsion systems than more complex the system is, the more uneven the evolution of its parts will be. in modifications to ship hulls.

Law of Transition to a Supersystem:

A technical system that has reached the limits of its evolution can continue to evolve at the supersystem level. Lines of the evolution of systems:

- Systems merging.

- Mono-bi-poly evolution.

- Convolution.

A one-colour pencil was replaced with a two-colour pencil, then with a multi-colour pencil, after which the drawing function was "transferred" to a printer.

\section{Laws of dynamics}

Law of Transition from Macro to Micro-Level:

The working organs of the system do initially evolve at a macro level, then the evolution is broken into micro-level processes Lines of the evolution of systems:

- Object segmentation.

- Surface segmentation.

- Volume voidness increase.

Increasing the degree of substance-field interactions

Systems tend to increase the number of elements and interactions between ele ments

Law of Increasing Degree of Dynamics of System and Elimination of Human Involvement:

To increase their efficiency, systems should become dynamic, that is, transform into flexible structures and quickly adapting to environmental conditions. The increase of dynamics, adaptability and versatility helps to decrease the involvement of a person necessary to control a system [34]. Lines of the evolution of systems:

A flat ruler was replaced by a folding joiner's meter, which, in turn, was developed into a measuring tape, then into a laser distance meter.

Segmentation of an object takes place when the solids used are subsequently replaced with granulate, powder, gel, liquid, gas, and plasma. For example, the typewriter was replaced by inkjet printing, which in turn was replaced by laser printing.

An incomplete system is completed to form a minimal technical system (consisting of two substances and one field), and the latter system is extended to form, for example, a chain substance-field or dual substance-field [8].

- Increasing the degree of freedom (dynamics) of an object.

- Increasing the dynamics of a substance.

- Increasing dynamics of a field.

Source: compiled on the basis of [1, 5, 34]. 


\section{SYSTEM OPERATOR}

Another tool used in TRIZ is the multi-screen diagram, also known as a system operator. This is a tool used to assess changes in successive generations of a system that occur during its evolution over time (past, present, and future) and at different system levels (supersystem, system, and subsystems). Based on a comparative analysis of past generations, it is possible to predict future directions of a given system's evolution. Figure 5 presents the evolution of container ships with large cargo capacities, considering the location of these ships in the global fleet, as well as their structural components (hull and propulsion system). The analysis also includes a forecast of the evolution of the system. Important elements of the development of this technology are the speed of the ship, capacity of the ship, and the emission of harmful substances in the exhaust gases of the propulsion engines.

Since it is the most common number of fields in a system operator, a multi-screen diagram is often called a $3 \times 3$ diagram or a 9-screen diagram. However, an analysis may be more extensive, and it may cover different levels of decomposition, e.g., $3 \times 4,4 \times 3,4 \times 4,5 \times 5$, etc. For example, the level of the subsystems may include a breakdown into functional systems/tissues, while those can be further broken down into working nodes/cells, and those into base elements/cellular organs, etc. Similarly, regarding the time scale, both the past and the future evolution of the system can be analysed at different points of the time axis, e.g., by analysing the evolution of the system in the future, e.g., in a month, in a year, in 10 years, etc.

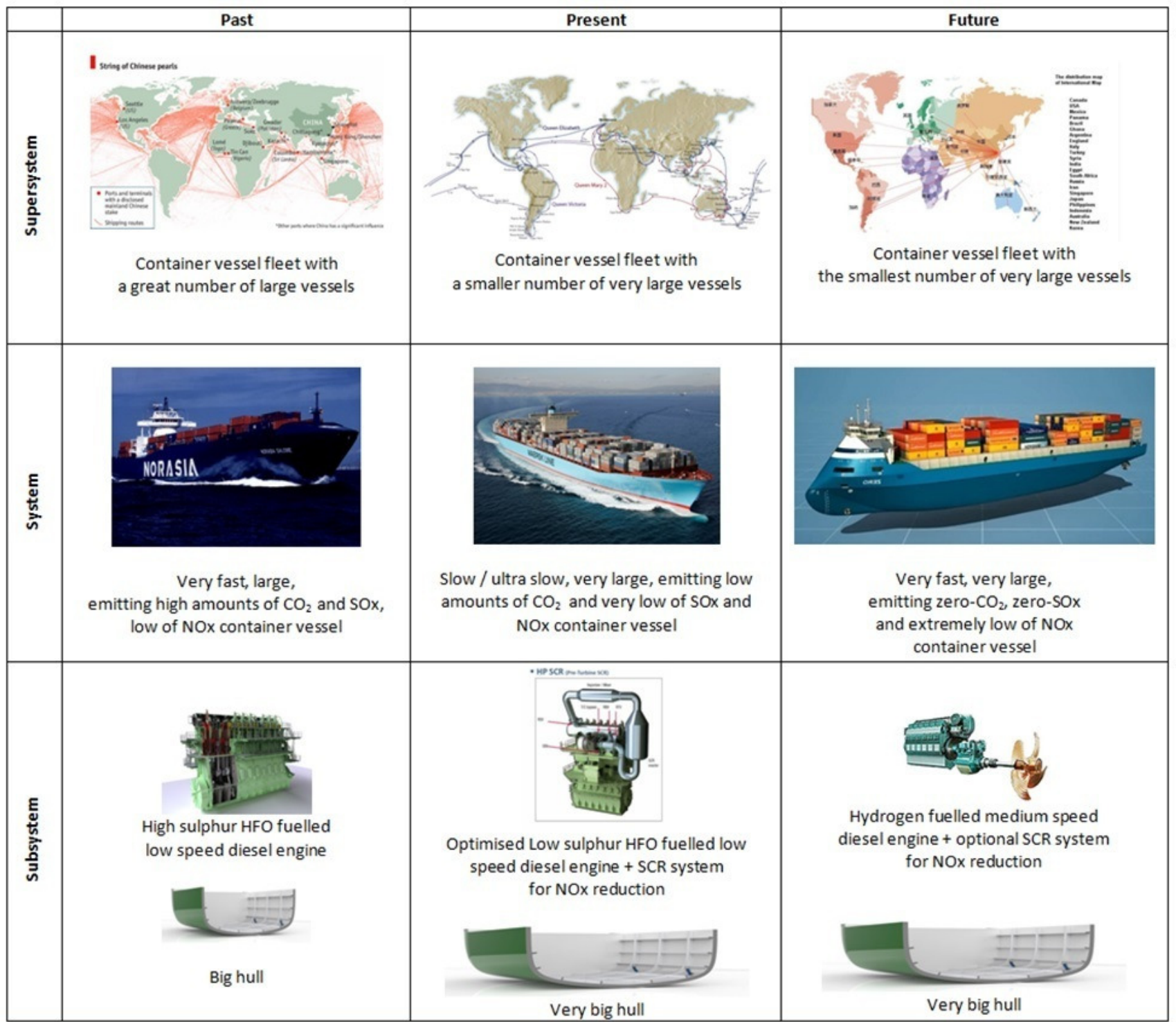

Fig. 5 Multi-screen diagram illustrating the development of large container ships 


\section{ANALYSIS OF THE SYSTEM'S EVOLUTIONARY POTENTIAL}

An evolution potential analysis is one of the tools used to assess the potential for the evolution of a system and thus to indirectly indicate the potential future generations of the analysed system. It is a simple tool used to present the multi-criteria state of the analysed technical system. Miscellaneous versions and applications of this tool have been presented in various works $[15,19,40]$ and have also been implemented in computer-aided innovation tools [2, 14, 26].

The analysis is carried out for various criteria, which may be the system evolution stages and evolution lines, as well as the specific features of the system within a given domain group. Each feature is assigned a specific value, usually stepwise, which corresponds to the degree of fulfilment of a given criterion. A convenient solution is to use a 0-10 scale. The results are represented with a radial graph by connecting the points that represent how well the analysed technical system fulfils the individual criteria (i.e. the level of evolution of particular trends and lines of evolution). An example of the analysis of the evolutionary potential of a classic marine engine fuel injector is presented in Figure 6 . The analysis included the results and findings presented in other reports $[3,17,18,28,30,41]$.

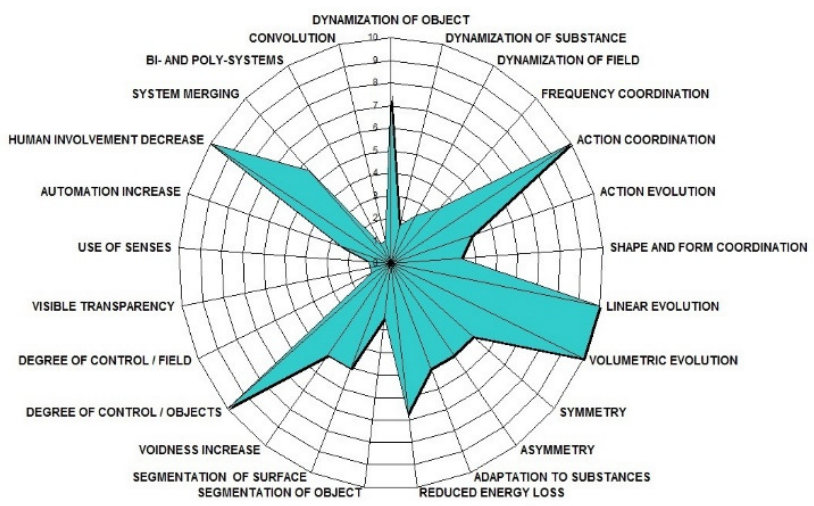

Fig. 6 An example of the analysis of the evolutionary potential of a classic marine combustion engine fuel injector

The field inside the graph illustrates the present status of the system, while the area not covered by the graph represents possibilities for further evolution of the system. For example, increasing the dynamics (number of degrees of freedom) of the above classic injector is possible by introducing additional fields in the control system, which in the form of an electrical field - was done using piezoelectric injectors, which are an advanced form of the analysed technical system. Another example may be an increase in the level of surface segmentation, which is presented in the paper [22] for an injector needle.

\section{THE INNOVATION ROADMAP}

Another tool that supports the process of technology development forecasting is the innovation roadmap. By analysing the evolutionary potential of a system, one can identify miscellaneous variants to improve particular features of a system by identifying sample solutions aimed at improving the product. For each of these solutions, a target level of fulfilment of specific trends and lines of evolution is determined. The outcome is the selection of the most useful solutions, which provide the greatest improvement in the system [19, 34, 39].

Individual solutions can be evaluated using decision-making methods, e.g., evaluation matrices or AHP $[10,11]$. Examples of criteria to be considered are: improvement in the efficiency of the implemented process, increase in the quality, reduction of harmful impact, reduction of production costs, product adaptation to the company's business model, improvement of the operation security, increase in reliability, etc. Aggregated or total values of individual solutions are set for the above-mentioned evaluation criteria. At the same time, the amount of time needed to implement individual solutions should be assessed. Individual pairs of solution values and the time taken to implement this solution are plotted on the innovation roadmap. An example of such a model for the analysis of the potential for developing a marine engine fuel injector is shown in Figure 7.

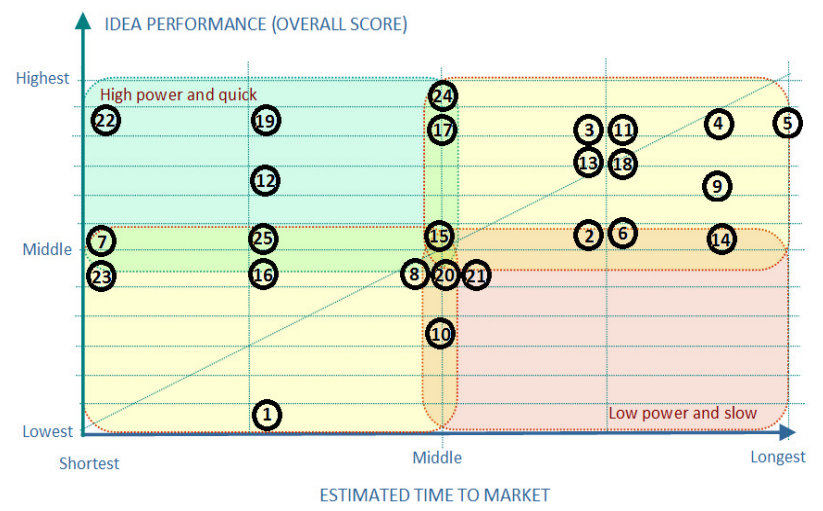

Fig. 7 Example of an innovation roadmap (prepared by the author) for the fuel injector of a marine combustion engine; 1-25 - variants of solutions

An assessment of the potential for the development of modern injectors resulted in the development of 25 examples for possible improvements. The most promising solutions are those located in the top left quarter of the innovation map, because these have been determined to have the highest value while requiring the shortest implementation time. Solutions located in the lower right quarter of the map are not very effective, so they will likely not be implemented in the product in the near future.

\section{COMPARISON OF METHODS}

The main advantages and disadvantages of each tool are summarised in Table 2. 
Comparison of TRIZ tools for assessing the development of technical systems

\begin{tabular}{cll}
\hline Tool & \multicolumn{1}{c}{ Advantages } & \multicolumn{1}{c}{ Disadvantages } \\
\hline & $\begin{array}{l}\text { The tool allows for a rough assessment } \\
\text { of where the system is in its development } \\
\text { in terms of a selected main parameter value (MPV). }\end{array}$ & $\begin{array}{l}\text { The tool is difficult to apply in order to determine the exact } \\
\text { phase of product development, primarily because many } \\
\text { main parameters of values (system characteristics) are deve- } \\
\text { loped simultaneously. }\end{array}$
\end{tabular}

The tool allows convenient retrospective analysis of The tool has limited applicability for systems with highly-dymultiple generations of the system from its creation namic development changes (e.g., due to sudden breakto-date. through discoveries)

Individual trends allow for a convenient assessment of Individual trends are fulfilled with varying intensities for the potential of technical systems' development in different products and their operation stages (state-of-the-

"Laws" and lines of technology development terms of selected criteria, e.g., energy conductivity, art, technological performance, changing consumer needs, dynamics of function implementation, coordination of etc.) activities, etc.

"The laws of evolution" reflect the most common evolution tendencies but are not without exceptions in applicability. Therefore, they are not laws according to the scientific definition of the term (e.g., Archimedes' principle is a law).

The tool makes it possible to assess the past stages of With multiple "screens", the tool can be difficult to use. technical system evolution and to infer conclusions

Multi-screen diagram about the future on this basis.

The tool allows the system to be evaluated at different levels of decomposition

The tool allows for practical visualization of potential The assessment of the state of technology evolution may be paths of technology development in terms of effec- subjective, so it is advisable to use additional analyses, e.g., tiveness of solutions and time to implement them. surveys among experts or product users.

Evolutionary potential The tool makes the comparative analysis of competing The obtained results of the evaluation of the system's evoanalysis systems possible. lutionary potential will be based solely on the criteria adopted during the analysis. Therefore, it is necessary to elaborate preliminary assumptions for the evaluation of the technology development

The innovation road

The tool allows for selection of possible solutions that The analysis of the effectiveness and time of implementamap

that are not very effective.

\section{SUMMARY}

All the tools listed in this article can be used to evaluate the development directions of technical systems at the problem analysis stage and to search for solutions. The presented tools can be used not only to predict the development of technology but also to actively develop and create solutions for the future. The issue of targeted product evolution has been described in other works [19, 27, 39]. In addition, Ideation International, Inc. is developing a specialized TRIZSoft ${ }^{\circledR}$ software that supports the targeted evolution process [20].

The presented methods can be used together or individually. They can also be used as an addition to other TRIZ tools $[2,7,13,25,35,36]$, as well as to other methods that forecast the development of technical systems and the evaluation of evolutionary potential $[6,13,19,26,37,38]$. The universality of the methods presented, allows one to analyse objects other than technical systems, e.g., a company's organisation, business strategies, scenarios of events in crisis management, etc.

\section{ACKNOWLEDGEMENTS}

The publication presents the results of research number $1 / S / I E S O / 17$, entitled "Increasing operational effectiveness of complex technical systems by systematic development and implementation of innovations using novel materials and modifying the object's structure" conducted at the Maritime University in Szczecin.

\section{REFERENCES}

[1] Altshuller G., Creativity as an Exact Science: The Theory of the Solution of Inventive Problems, Gordon and Breach Publishers, 1984.

[2] AULIVE. Online: http://www.aulive.com/ [dostęp: 27.09.2018].

[3] Bajer A., Żółkiewski S., Initial research of epoxy and polyester warp laminates testing on abrasive wear used in car sheathing. Eksploatacja i Niezawodność 15, 2013, s. 37-43.

[4] Basalla G., The Evolution of Technology. Cambridge. Cambridge University Press 1989, doi: 10.1017/CBO9781107049864.002. 
[5] Boratyńska-Sala A., Prawa rozwoju systemów technicznych jako narzędzie kształtowania nowego produktu. $Z a-$ rzqdzanie Przedsiębiorstwem, 20(4), 2017, s. 2-9.

[6] Chybowska D., Chybowski L., Souchkov V., R\&D in Poland: Is the Country Close to a Knowledge-Driven Economy? Management Systems in Production Engineering, Vol. 26, Issue 2, s. 99-105, 2018, doi: 10.1515/mspe-2018-0016.

[7] Chybowski L., The usage of the Miniature Dwarfs method in the improvement of passenger ship construction. Scientific Journals of the Maritime University of Szczecin, Zeszyty Naukowe Akademii Morskiej w Szczecinie, nr 51 (123), 2017, s. 28-34, doi: 10.17402/227.

[8] Chybowski L., Use of TRIZ Su-Field models in the process of improving the injector of an internal combustion engine. MAPE - Multidisciplinary Aspects of Production Engineering. Proceedings of XV International Conference Multidisciplinary Aspects of Production Engineering. Zawiercie 2018, Vol. 1, Issue 1, s. 257-268, doi: 10.2478/mape-20180033.

[9] Chybowski L., Chybowska D., Polskojęzyczne piśmiennictwo dotyczące teorii rozwiązywania innowacyjnych zadań a popularność tej metodologii (red. Ryszard Knosala) Innowacje w zarządzaniu i inżynierii produkcji. Tom I. Oficyna Wydawnicza Polskiego Towarzystwa Zarządzania Produkcją, Opole 2018, s. 11-22.

[10] Chybowski L., Gawdzińska K., On the Possibilities of Applying the AHP Method to a Multi-criteria Component Importance Analysis of Complex Technical Objects. Advances in Intelligent Systems and Computing 445, 2016, s. 701-710, doi: 10.1007/978-3-319-31307-8_71.

[11] Chybowski L., Gawdzińska K., Przetakiewicz W., AHP based multi-criteria function analysis as a TRIZ tool for complex technical systems (Ed. Valeri Souchkov) Proceedings of the 13th MATRIZ TRIZfest 2017 International Conference. International TRIZ Association - MATRIZ, Knoxville 2017, s. 31-45.

[12] Chybowski L. Idziaszczyk D., Metody tworzenia innowacyjnych rozwiązań technicznych - TRIZ - Teoria Rozwiązywania Innowacyjnych Zagadnień. Industrial Monitor - produkcja i utrzymanie ruchu, $\mathrm{Nr}$ Q2/(16) 2015, 40-44. Online: http://www.industrial-monitor.pl/wydania/IM_16_(2Q2015)/index.html\#/41 [dostęp: 25.09.2018].

[13] Chybowski L., Twardochleb M., Wiśnicki B., Multi-criteria Decision making in Components Importance Analysis applied to a Complex Marine System, Naše more, 63 (4), s. 264-270, 2016, doi: 10.17818/NM/2016/4.3.

[14] CREAX. Online: https://www.creax.com [dostęp: 27.09.2018].

[15] Darrell M., Dewulf S., Evolutionary-Potential ${ }^{\mathrm{TM}}$ in Technical and Business Systems. The TRIZ Journal, 14.06.2002. Online: https://triz-journal.com/evolutionary-potentialtechnical-business-systems/[dostęp: 25.09.2018].

[16] Derlukiewicz, D., Ptak, M., Koziołek, S., 2016. Proactive Failure Prevention by Human-Machine Interface in RemoteControlled Demolition Robots, in: Advances in Intelligent Systems and Computing. pp. 711-720. doi:10.1007/978-3319-31307-8_72

[17] Gawdzińska K., Grabian J., Przetakiewicz W., Use of X-ray radiography in finding defects in metal-matrix composite casts. Metalurgija 47(3), 2008, s. 199-201.

[18] Gawdzińska K., Bryll K., Nagolska D., Influence of heat treatment on abrasive wear resistance of silumin matrix composite castings. Archives of Metallurgy and Materials 61(1), 2016, s. 177-182, doi: 10.1515/amm-2016-0031.
[19] Harrington H. J. et al. The Directed Evolution methodology: A collection of tools, software and methods for creating systemic change. TQM Journal 24(3), 2012, s. 204-217, doi: 10.1108/17542731211226736.

[20] Ideation International Inc. TRIZSoft ${ }^{\circledR}$ software. Online: http://www.whereinnovationbegins.net/software/[dostęp: 29.09.2018].

[21] Karliński, J., Ptak, M., Działak, P., Rusiński, E., 2016. The approach to mining safety improvement: Accident analysis of an underground machine operator. Arch. Civ. Mech. Eng. 16, 503-512. doi:10.1016/j.acme.2016.02.010.

[22] Klyus O., Wykorzystanie zjawiska turbulizacji przy wstępnej obróbce paliwa w silnikach z zapłonem samoczynnym. Combustiuon Engines, 3(138), 2009, 49-53. Online: http://yadda.icm.edu.pl/yadda/element/bwmeta1.element.baztech-article-LOD9-0013-

0006/c/httpwww_bg_utp_edu_plartsilniki20spalinowe2009ptnss-2009-ss3-c038.pdf [dostęp: 27.09.2018].

[23] Koziołek, S., Derlukiewicz, D., Ptak, M., 2010. Design Process Innovation of Mechanical Objects with the Use of Design for Six Sigma Methodology, in: Solid State Phenomena. pp. 274-279. doi:10.4028/www.scientific.net/SSP.165.274

[24] Lyubomirskiy A. et al., Trends of Engineering System Evolution (TESE). TRIZ paths to innovation. Selbstverlag 2018.

[25] Mayer O., Flexible lighting distribution on "party ships". Scientific Journals of the Maritime University of Szczecin, Zeszyty Naukowe Akademii Morskiej w Szczecinie, nr 49 (121), 2017, s. 9-16, doi: 10.17402/195.

[26] Midor K., Klimecka-Tatar D., Chybowski L., Innowacje w przemyśle - wybrane aspekty. PA NOVA S.A., Gliwice 2017.

[27] Mizrachi Y., Don't Predict the Future - Direct It! Ideation International Inc. 2007. Online: http://www.whereinnovationbegins.net/build/wp-content/uploads/2017/01/DEConceptsandApplications.pdf [dostęp: 27.09.2018].

[28] Pajor, M., Grudziński, M., Intelligent machine tool - vision based 3D scanning system for positioning of the workpiece. Solid State Phenomena 220-221, 2015, s. 497503, doi: 10.4028/www.scientific.net/SSP.220-221.497.

[29] Prus B., O odkryciach i wynalazkach [w:] Kurs na wynalazczość! Zainspiruj się i cała naprzód! (red. D. Chybowska, L. Chybowski). Akademia Morska w Szczecinie, Szczecin, 2017.

[30] Sakow, M. et al., Unilateral hydraulic telemanipulation system for operation in machining work area. Lecture Notes in Mechanical Engineering 201519, 2018, s. 415-425, doi: 10.1007/978-3-319-68619-6_40.

[31] Samek A., Bionika. Wiedza przyrodnicza dla inżynierów. Wydawnictwa AGH, Kraków 2010.

[32] Slocum M. S., Technology Maturity Using S-curve Descriptors. The TRIZ Journal, 01.12.1998. Online: https://triz-journal.com/technology-maturity-using-s-curve-descriptors/[dostęp: 25.09.2018].

[33] Souchkov V., A Brief History of TRIZ. The TRIZ Journal, 22.09.2015. Online: https://triz-journal.com/a-brief-history-of-triz/ [dostęp 25.09.2018].

[34] Souchkov V., TRIZ and xTRIZ Techniques For Technology and Engineering Applications Training Course Techniques: Advanced Part. ICG Training \& Consulting, Enschede, 2016.

[35] Souchkov V., Application of Root Conflict Analysis (RCA+) to formulate inventive problems in the maritime industry. Scientific Journals of the Maritime University of Szczecin, Zeszyty Naukowe Akademii Morskiej w Szczecinie, nr 51 (123), 2017, s. 9-17, doi: 10.17402/225. 
[36] Souchkov V., TRIZ: Theory of Solving Inventive Problems to support engineering innovation in maritime industry. Scientific Journals of the Maritime University of Szczecin, Zeszyty Naukowe Akademii Morskiej w Szczecinie, nr 55 (127), 2018, s. 9-19, doi: 10.17402/297.

[37] UNIDO, Foresight Technologiczny, Podręcznik Tom 1 i 2. Organizacja Narodów Zjednoczonych ds. Rozwoju Przemysłowego, Wiedeń 2005.

[38] Wiśnicki B. et al., The Concept of the Development of Intermodal Transport Network Illustrated by Polish Market, Naše more, 64 (1), s. 33-37, 2017, doi: 10.17818/NM/2017/1.6.

\section{Dorota Chybowska}

Maritime University of Szczecin

Technology Transfer Office

ul. Wały Chrobrego 1-2, 70-500 Szczecin, Poland

tel.: +48914809412

e-mail: d.chybowska@am.szczecin.pl

ORCID ID: 0000-0002-9165-6931

\section{Leszek Chybowski}

Maritime University of Szczecin

Faculty of Marine Engineering

ul. Wały Chrobrego 1-2, 70-500 Szczecin, Poland

e-mail: I.chybowski@am.szczecin.pl

ORCID ID: 0000-0003-0245-3946
[39] Zlotin B., Zusman A., Directed Evolution. Philosophy, theory and practice. Ideation International Inc. 2001.

[40] Zlotin B., Zusman A., Hallfell F., TRIZ to invent your future utilizing directed evolution methodology. Procedia Engineering 9, 2011, s. 126-134. Online: https://core.ac.uk/download/pdf/82669665.pdf [dostęp: 27.09.2018].

[41] Żółkiewski S., Selection and impact of parameters in composite materials designing. Proceedings of the 13th IFToMM Congress, Guanajuato, Mexico 2011. 